\title{
Efficiency of utilization of essential amino acids in growing rats at different levels of intake
}

\author{
BY J. HEGER* AND Z. FRYDRYCH \\ Research Institute of Feed Supplements and Veterinary Drugs, \\ 25449 Jílové, Czechoslovakia
}

(Received 28 August 1984 - Accepted 22 April 1985)

\begin{abstract}
1. Nitrogen balance was studied in growing male SPF-rats fed on diets in which each essential amino acid was varied from zero to about $120 \%$ of optimum requirement. From the balance results, optimum and maintenance requirements were estimated as well as the efficiency of utilization of amino acids for growth and growth + maintenance.

2. $\mathrm{N}$ balance increased with increasing dietary level of the deficient amino acid; the response gradually diminished as the content of the amino acid approached optimum. At zero level of intake, negative $\mathrm{N}$ balance was found for all amino acids except histidine. The highest loss of body $\mathrm{N}$ was found in the sulphur-amino-acid-free diet and the lowest one in the lysine-free diet.

3. Maximal utilization of essential amino acids for growth was found at dietary levels corresponding to $30-60 \%$ of optimum requirement and ranged from about 0.65 to 0.85 except for $S$ amino acids and histidine. The utilization of $\mathrm{S}$ amino acids was about 0.55 while that of histidine exceeded 1.0 . The utilization of amino acids for growth + maintenance was maximal at the lowest levels of intake and gradually decreased as the dietary concentration of the limiting amino acid increased. At dietary levels near optimum the utilization was about $0.6-0.7$, except for $S$ amino acids where the utilization was less than $0 \cdot 5$.
\end{abstract}

The percentage of ingested nitrogen retained in the body is widely used as a criterion of dietary protein quality. A similar approach yielding more detailed information can be used for the assessment of utilization of individual amino acids. Earlier studies, based mainly on carcass analysis, demonstrated that the efficiency of utilization of dietary amino acids for the synthesis of body protein depended both on the type of amino acid and on its level in the diet. While the utilization of non-essential amino acids exceeded in most cases 1.0 due to their synthesis in the body (King, 1963), the values found for essential amino acids were always lower than 1.0 (King, 1963; Bunce \& King, 1969a,b). Of the latter, limiting amino acids were retained most efficiently (Pellett \& Kaba, 1972).

Until now, the efficiency of amino acid utilization was studied either with proteins or with amino acid mixtures of constant composition. However, the utilization of amino acids under these conditions was necessarilly affected by the degree of deficiency or surplus relative to their optimum requirements and therefore the comparison of values obtained for individual amino acids was rather questionable. Hence, the aim of the experiments reported here was to study the efficiency of utilization of each essential amino acid included in otherwise adequate diets in levels ranging from zero to about $120 \%$ of optimum requirement.

\section{EXPERIMENTAL}

Male SPF-rats of the Wistar strain, aged 21-23 d and weighing about $65 \mathrm{~g}$ were used. During the $4 \mathrm{~d}$ adjustment period, the animals were allowed to consume $a d$ lib. a casein-based diet containing $100 \mathrm{~g}$ crude protein $(\mathrm{N} \times 6 \cdot 25) / \mathrm{kg}$. They were then divided according to their body-weights into approximately homogenous groups of four to six rats, placed into individual metabolism cages and fed on experimental diets. The daily amount of diet offered

* Present address: Research Centre of Feed Supplements, Na Chvalce 2049, 25096 Praha 9, Horni Počernice, Czechoslovakia. 
Table 1. Composition of basal diet $(\mathrm{g} / \mathrm{kg})$

\begin{tabular}{lr}
\hline Wheat starch & $200 \cdot 0$ \\
Sucrose & $534 \cdot 6$ \\
Polyethylene & $50 \cdot 0$ \\
Soya-bean oil & $50 \cdot 0$ \\
Mineral mixture USP XVIII* & $50 \cdot 0$ \\
Vitamin mixture USP XVIII* & $10 \cdot 0$ \\
L-Arginine hydrochloride & $7 \cdot 3$ \\
L-Histidine & $3 \cdot 0$ \\
L-Isoleucine & $5 \cdot 0$ \\
L-Leucine & $7 \cdot 5$ \\
L-Lysine hydrochloride & $8 \cdot 7$ \\
L-Phenylalanine & $5 \cdot 0$ \\
L-Tyrosine & $3 \cdot 0$ \\
L-Threonine & $5 \cdot 0$ \\
L-Tryptophan & 1.5 \\
L-Valine & $6 \cdot 0$ \\
L-Methionine & $4 \cdot 0$ \\
L-Cystine & $2 \cdot 0$ \\
Non-essential amino acid mixture $\dagger$ & $47 \cdot 4$ \\
\hline
\end{tabular}

* According to the Association of Official Agricultural Chemists (1970).

$\dagger$ Contained $(\mathrm{g} / \mathrm{kg})$ : L-alanine 65 , L-asparagine 85 , L-glutamine 24 , L-aspartic acid 65 , L-glutamic acid 25 , glycine 265 , L-proline 19 , L-serine 65 .

Table 2. Expts 1-9. Dietary levels of essential amino acids $(\mathrm{g} / \mathrm{kg})^{*}$ (Five animals per treatment except where shown in parentheses)

\begin{tabular}{|c|c|c|c|c|c|c|c|c|c|c|}
\hline \multirow{2}{*}{$\begin{array}{l}\text { Expt } \\
\text { no. }\end{array}$} & \multirow[b]{2}{*}{ Amino acid } & \multicolumn{9}{|c|}{ Dietary level $(\mathrm{g} / \mathrm{kg})$} \\
\hline & & 1 & 2 & 3 & 4 & 5 & 6 & 7 & 8 & 9 \\
\hline 1 & Lysine & 0.02 & 1.42 & 2.82 & $4 \cdot 18$ & 5.62 & $7 \cdot 02$ & $8 \cdot 34$ & - & - \\
\hline 2 & Leucine & 0.08 & $1 \cdot 54$ & 3.00 & $4 \cdot 46$ & $\begin{array}{c}4.58 \\
(6)\end{array}$ & $\begin{array}{l}6.08 \\
(6)\end{array}$ & $\begin{array}{l}7 \cdot 58 \\
(4)\end{array}$ & $\begin{array}{l}9 \cdot 08 \\
(6)\end{array}$ & - \\
\hline 3 & $\begin{array}{l}\text { Phenylalanine } \\
\text { +tyrosine }\end{array}$ & $0 \cdot 10$ & 1.54 & 2.98 & $4 \cdot 42$ & $6 \cdot 50$ & $8 \cdot 10$ & $9 \cdot 70$ & - & - \\
\hline 4 & Valine & $\begin{array}{l}0.05 \\
(6)\end{array}$ & $1 \cdot 15$ & $2 \cdot 25$ & $\begin{array}{l}3 \cdot 35 \\
(4)\end{array}$ & 3.65 & $4 \cdot 85$ & $\begin{array}{c}6.05 \\
(4)\end{array}$ & $7 \cdot 25$ & - \\
\hline 5 & $\begin{array}{l}\text { Methionine } \\
\text { +cystine }\end{array}$ & 0.02 & $\begin{array}{c}0.74 \\
(4)\end{array}$ & 1.25 & $\begin{array}{c}2 \cdot 45 \\
(4)\end{array}$ & $\begin{array}{c}2.94 \\
(4)\end{array}$ & $\begin{array}{c}3.65 \\
(6)\end{array}$ & 4.85 & $6 \cdot 05$ & $\begin{array}{l}7.25 \\
(4)\end{array}$ \\
\hline 6 & Threonine & 0.03 & 1.03 & $2 \cdot 03$ & 3.03 & 4.03 & $\begin{array}{l}5 \cdot 03 \\
(4)\end{array}$ & $6 \cdot 03$ & - & - \\
\hline 7 & Isoleucine & $0 \cdot 05$ & 0.83 & $2 \cdot 05$ & 3.05 & $3 \cdot 30$ & $\begin{array}{l}4 \cdot 05 \\
(4)\end{array}$ & $5 \cdot 05$ & $\begin{array}{c}6 \cdot 05 \\
(6)\end{array}$ & - \\
\hline 8 & Histidine & $\begin{array}{c}0.03 \\
(4)\end{array}$ & 0.63 & $1 \cdot 23$ & $1 \cdot 83$ & $2 \cdot 43$ & $3 \cdot 03$ & 3.63 & - & - \\
\hline 9 & Tryptophan & 0.01 & 0.22 & 0.43 & 0.64 & $\begin{array}{l}0.91 \\
(4)\end{array}$ & 1.21 & $\begin{array}{l}1.51 \\
(4)\end{array}$ & $1 \cdot 81$ & - \\
\hline
\end{tabular}

* Including the amount of amino acids contained in wheat starch. 
Lysine

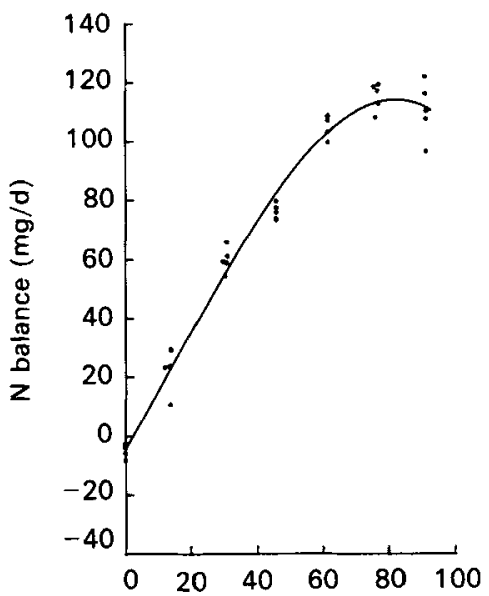

Leucine

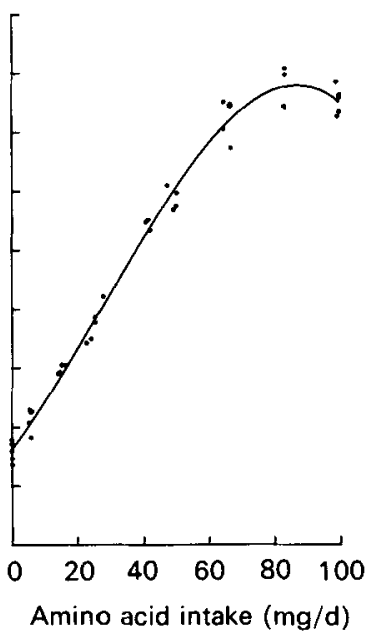

Phenylalane + tyrosine

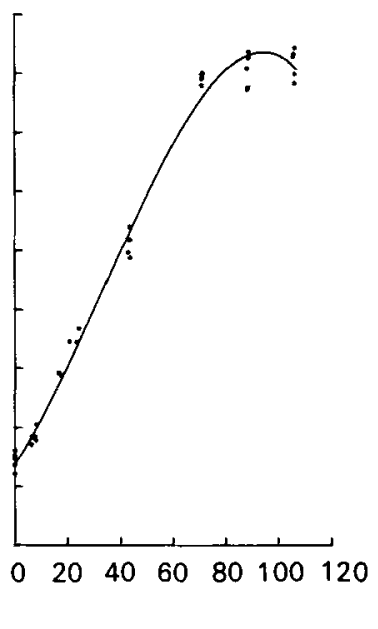

Fig. 1. Expts 1-3. The relation between nitrogen balance and amino acid intake in growing rats given essential amino acids at different levels of intake.
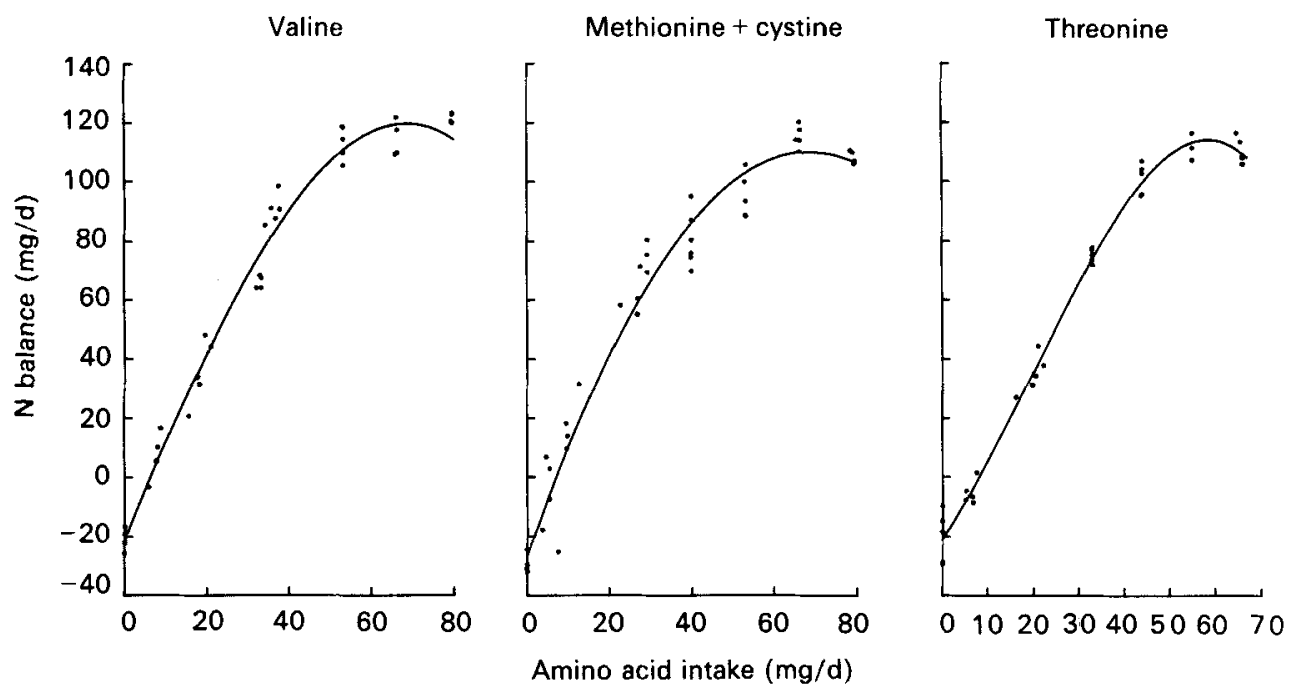

Fig. 2. Expts 4-6. The relation between nitrogen balance and amino acid intake in growing rats given essential amino acids at different levels of intake.

was $11 \mathrm{~g}$. The balance period consisted of a $4 \mathrm{~d}$ preliminary period and a $6 \mathrm{~d}$ collection period during which faeces and urine were collected quantitatively. Details of the balance procedure have been described previously (Heger et al. 1983). In all experiments, purified diets were used containing crystalline amino acids in amounts equivalent to the optimum requirements of growing rats ((US) National Research Council, 1978) as the only source of $\mathrm{N}$. The composition of the basal diet is presented in Table 1. The dietary content of each amino acid under study changed from zero to approximately $120 \%$ of the optimum requirement. In the case of sulphur and aromatic amino acids, the ratio methionine: cystine 

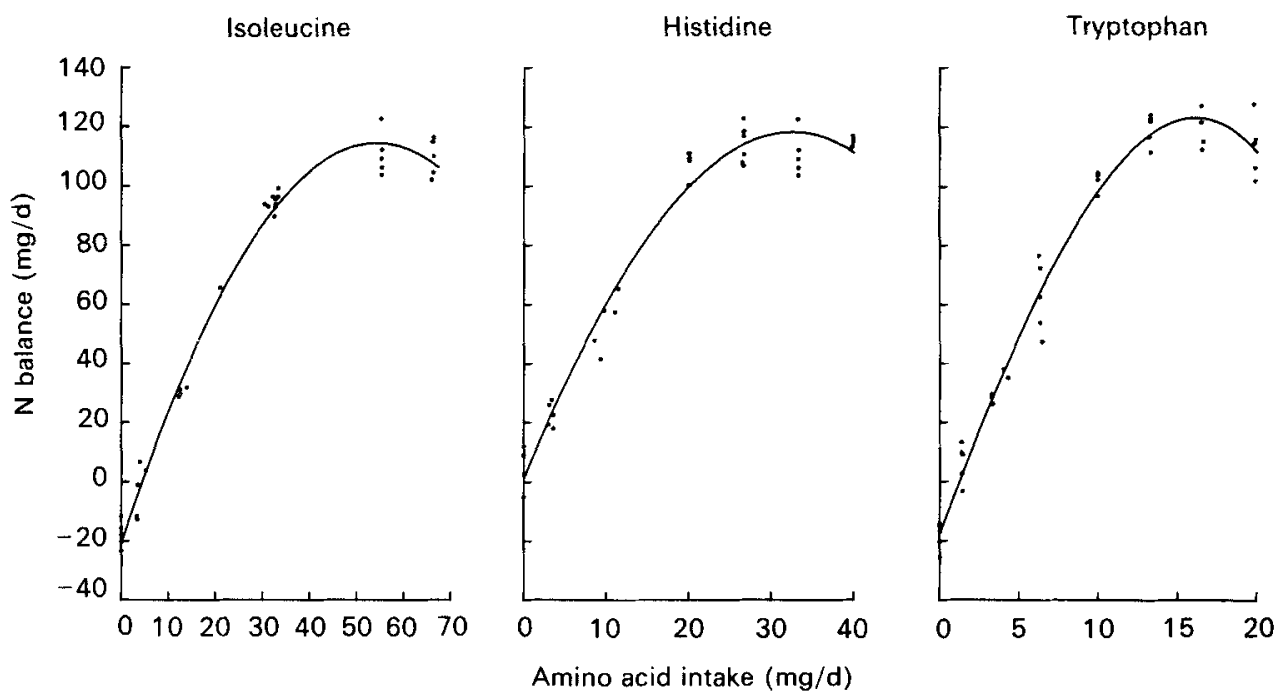

Fig. 3. Expts 7-9. The relation between nitrogen balance and amino acid intake in growing rats given essential amino acids at different levels of intake.

Table 3. Coefficients of polynomials expressed by the equation

$$
y=a_{0}+a_{1} x+a_{2} x^{2}+a_{3} x^{3}
$$

obtained by fitting nitrogen $(y) \mathrm{v}$. amino acid intake $(x)$

\begin{tabular}{|c|c|c|c|c|c|}
\hline \multirow[b]{2}{*}{ Amino acid } & \multicolumn{4}{|c|}{ Coefficient } & \multirow[b]{2}{*}{$F$ ratio* } \\
\hline & $a_{0}$ & $a_{1}$ & $a_{2}$ & $a_{3}$ & \\
\hline Lysine & $-4 \cdot 172$ & 1.927 & $5.743 \times 10^{-3}$ & $-1.421 \times 10^{-4}$ & 586 \\
\hline Leucine & $-7 \cdot 519$ & $1 \cdot 486$ & $1.503 \times 10^{-2}$ & $-1.817 \times 10^{-4}$ & 1406 \\
\hline Phenylalanine + tyrosine & $-12 \cdot 482$ & $1 \cdot 365$ & $1.812 \times 10^{-2}$ & $-1.793 \times 10^{-4}$ & 1188 \\
\hline Isoleucine & $-20 \cdot 645$ & $4 \cdot 749$ & $-3.465 \times 10^{-2}$ & $-1.185 \times 10^{-4}$ & 1124 \\
\hline Threonine & -20.692 & $2 \cdot 271$ & $4.010 \times 10^{-2}$ & $-6.760 \times 10^{-4}$ & 1224 \\
\hline $\begin{array}{l}\text { Methionine } \\
\text { + cystine }\end{array}$ & $-26 \cdot 608$ & $3 \cdot 948$ & $-2.811 \times 10^{-2}$ & $-6.216 \times 10^{-6}$ & 407 \\
\hline Histidine & $0 \cdot 808$ & 6.875 & $-8.947 \times 10^{-2}$ & $-3.332 \times 10^{-4}$ & 359 \\
\hline Valine & $-20 \cdot 978$ & $3 \cdot 380$ & $-8.752 \times 10^{-3}$ & $-1.547 \times 10^{-4}$ & 565 \\
\hline Tryptophan & $-17 \cdot 781$ & $14 \cdot 501$ & $-1.704 \times 10^{-1}$ & $-1.158 \times 10^{-2}$ & 616 \\
\hline
\end{tabular}

* Regression mean squares: residual mean squares.

or phenylalanine: tyrosine was the same as in the basal diet. The total content of $\mathrm{N}$ in the diet was maintained at the same level $(16 \mathrm{~g} / \mathrm{kg})$ by adjustment of the non-essential amino acid mixture. Levels of essential amino acids used in individual experiments are presented in Table 2. The values include also the amount of amino acids contained in wheat starch which was calculated from the $\mathrm{N}$ content of starch $(0.8 \mathrm{~g} / \mathrm{kg})$ and amino acid concentration in wheat gluten (Nehring et al. 1972). Table 2 also gives the numbers of rats per treatment.

The relation between the dietary level of amino acids and $\mathrm{N}$ balance was evaluated by regression analysis using polynomials of the third degree. The dietary intake of amino acid corresponding to the maximum response was considered as the optimum requirement while the maintenance requirement was estimated from the point of intersection of the regression 
Table 4. Comparison of essential amino acid requirements of the growing rat

\begin{tabular}{|c|c|c|c|c|}
\hline \multirow[b]{2}{*}{ Amino acid } & \multicolumn{2}{|c|}{ Growth $(\mathrm{g} / \mathrm{kg}$ diet $)$} & \multicolumn{2}{|c|}{$\begin{array}{l}\text { Maintenance }(\mathrm{mg} / \mathrm{kg} \\
\text { body-wt }\end{array}$} \\
\hline & $\begin{array}{l}\text { Present } \\
\text { results }\end{array}$ & $\begin{array}{c}\text { (US) National } \\
\text { Research Council } \\
(1978)\end{array}$ & $\begin{array}{l}\text { Present } \\
\text { results }\end{array}$ & $\begin{array}{c}\text { Yoshida \& } \\
\text { Ashida (1969) }\end{array}$ \\
\hline Lysine & $7 \cdot 5$ & $7 \cdot 0$ & 11 & 12 \\
\hline Threonine & $5 \cdot 3$ & $5 \cdot 0$ & 54 & 40 \\
\hline Isoleucine & $4 \cdot 9$ & $5 \cdot 0$ & 31 & 44 \\
\hline Leucine & $7 \cdot 9$ & $7 \cdot 5$ & 31 & 64 \\
\hline $\begin{array}{l}\text { Methionine } \\
\text { + cystine }\end{array}$ & $6 \cdot 2$ & $6 \cdot 0$ & 43 & 20 \\
\hline Histidine & $3 \cdot 0$ & $3 \cdot 0$ & - & 16 \\
\hline $\begin{array}{l}\text { Phenylalanine } \\
\text { + tyrosine }\end{array}$ & $8 \cdot 6$ & $8 \cdot 0$ & 52 & 48 \\
\hline Valine & $6 \cdot 2$ & $6 \cdot 0$ & 40 & 44 \\
\hline Tryptophan & $1 \cdot 5$ & 1.5 & 8 & 8 \\
\hline
\end{tabular}

curve with the zero balance point. The maximum response was calculated as the first derivative of the regression function. Based on the regression functions, the utilization of each amino acid for growth and growth + maintenance was calculated. The utilization for growth was defined as the proportion of consumed amino acid which was retained in the body. Amino acid retention was calculated from $\mathrm{N}$ balance and mean amino acid composition of rat carcasses of similar weight as reported by Pellett \& Kaba (1972). The utilization for growth and maintenance was calculated similarly; however, the amount of amino acid retained was increased by adding the maintenance requirement.

\section{RESULTS}

The response of $\mathbf{N}$ balance to dietary levels of each essential amino acid is shown in Figs 1-3. Coefficients of polynomials fitted to the experimental values are given in Table 3. $\mathrm{N}$ balance increased with increasing level of deficient amino acid in the diet; however, the response gradually diminished as the content of amino acid tested approached optimum requirement. Beyond the optimum level, $\mathrm{N}$ balance remained unchanged or slightly decreased. At zero level of intake, a negative $\mathrm{N}$ balance was found for all the amino acids except histidine; the rats on the histidine-free diet showed slightly positive $\mathrm{N}$ balance. The highest loss of body $\mathrm{N}$ was found in rats fed on a S-amino-acid-free diet followed, in decreasing order, by diets devoid of valine, threonine, isoleucine, tryptophan, aromatic amino acids, leucine and lysine.

Table 4 summarizes the mean estimates of essential amino acid requirements for growth and for maintenance derived from the present experiments compared with the recommendations of (US) National Research Council (1978) and values from Yoshida \& Ashida (1969). Owing to the differences in food intake and body-weight of rats fed on deficient diets, the maintenance requirements were calculated per $\mathrm{kg}$ metabolic body-weight $\left(\mathrm{W}^{0}{ }^{\mathbf{7} 75}\right)$.

Figs. 4 and 5 show the relations between the intake of amino acids expressed as a percentage of calculated optimum requirement and their efficiency of utilization for growth and growth + maintenance. Coefficients of functions describing these relations are given in Table 5. Maximum utilization for growth was obtained at dietary levels equivalent to 


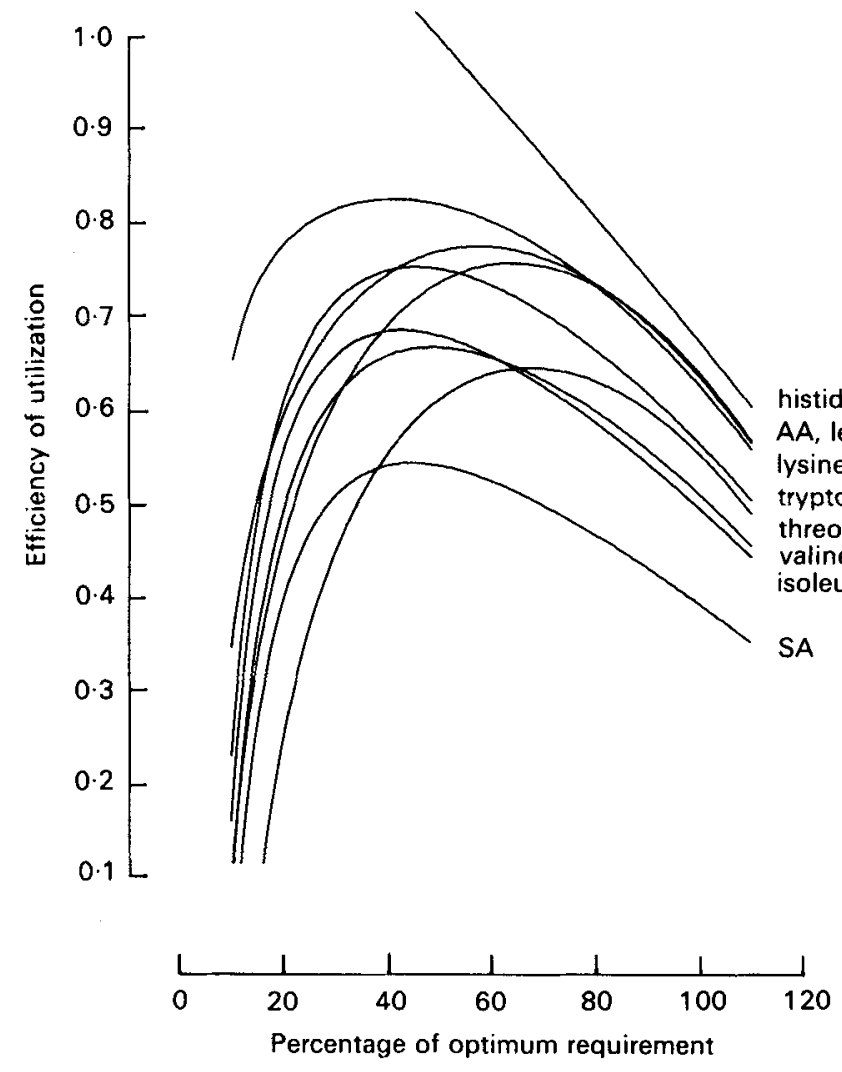

Fig. 4. Predicted efficiency of utilization of essential amino acids for growth at different levels of intake in rats. SA, sulphur-containing amino acids; AA, aromatic amino acids.

$30-60 \%$ of optimum requirement and ranged from about 0.65 to 0.85 , except for $S$-containing amino acids and histidine. Maximum efficiency of utilization of methionine + cystine was about 0.55 while that of histidine exceeded 1.0 at lower dietary levels. The utilization of amino acids for growth and maintenance measured at the lowest dietary intakes approached 1.0 and gradually decreased as the concentration of the deficient amino acid in the diet increased. At the dietary levels near optimum requirement about $60-75 \%$ of ingested amino acids were retained except for S-containing amino acids where the utilization was below 0.5 under these conditions.

\section{DISCUSSION}

The relation between the dietary level of amino acids and $\mathrm{N}$ balance seems to confirm the assumption of the sigmoidal shape of the dose-response curve (Hegsted, 1964). A similar type of curve was obtained by Yoshida \& Ashida (1969) who studied the relation between the level of limiting amino acid in the diet and body-weight changes of growing rats. Various models have been proposed for the mathematical interpretation of the dose-response curve; however, each of them have certain drawbacks. The linear model advocated by Hegsted (1964) almost always underestimates the optimum dose (Morris, 1983). This was confirmed also in the present study: the optimum requirements estimated from the intersection of the 

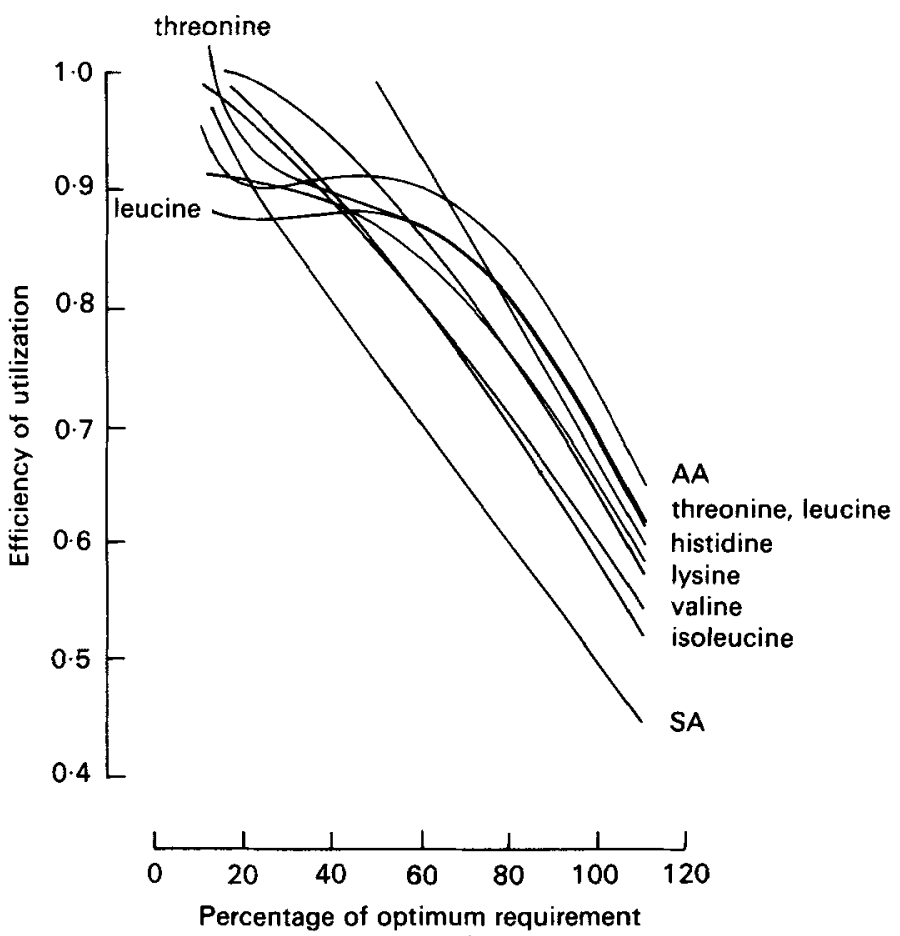

Fig. 5. Predicted efficiency of utilization of essential amino acids for growth + maintenance at different levels of intake in rats. SA, sulphur-containing amino acids; AA, aromatic amino acids.

Table 5. Coefficients of functions expressed by the equation

$$
y=a_{0} x^{-1}+a_{1}+a_{2} x+a_{3} x^{2}
$$

describing the relation between amino acid intake $(x)$ and its efficiency of utilization for growth $(g)$ or growth + maintenance $(g+m)$

\begin{tabular}{|c|c|c|c|c|c|}
\hline \multirow[b]{3}{*}{ Amino acid } & \multicolumn{5}{|c|}{ Coefficient } \\
\hline & \multicolumn{2}{|c|}{$a_{0}$} & \multirow[b]{2}{*}{$a_{1}$} & \multirow[b]{2}{*}{$a_{2}$} & \multirow[b]{2}{*}{$a_{3}$} \\
\hline & $g$ & $g+m$ & & & \\
\hline Lysine & $-1 \cdot 881$ & 0.269 & 0.869 & $2 \cdot 590 \times 10^{-3}$ & $-6.407 \times 10^{-5}$ \\
\hline Leucine & $-3 \cdot 579$ & $1 \cdot 261$ & 0.708 & $7 \cdot 155 \times 10^{-3}$ & $-8.650 \times 10^{-5}$ \\
\hline $\begin{array}{l}\text { Phenylalanine } \\
\text { +tyrosine }\end{array}$ & -5.929 & $2 \cdot 371$ & 0.649 & $8.609 \times 10^{-3}$ & $-8.518 \times 10^{-5}$ \\
\hline Isoleucine & $-4 \cdot 748$ & -0.248 & $1 \cdot 101$ & $-7.969 \times 10^{-3}$ & $-2.726 \times 10^{-5}$ \\
\hline Threonine & -5.897 & $2 \cdot 213$ & 0.647 & $1.143 \times 10^{-2}$ & $-1.927 \times 10^{-4}$ \\
\hline Methionine + cystine & -6.572 & 0.528 & 0.975 & $-6.493 \times 10^{-3}$ & $-1.535 \times 10^{-6}$ \\
\hline Histidine & $0 \cdot 150$ & $2.954 \times 10^{-2}$ & 1.272 & $-1.655 \times 10^{-2}$ & $-6 \cdot 165 \times 10^{-5}$ \\
\hline Valine & $-6 \cdot 147$ & $0 \cdot 173$ & 0.990 & $-2.564 \times 10^{-3}$ & $-4.531 \times 10^{-5}$ \\
\hline Tryptophan & $-1 \cdot 316$ & $-6.576 \times 10^{-2}$ & 1.073 & $-1.261 \times 10^{-2}$ & $-8.570 \times 10^{-4}$ \\
\hline
\end{tabular}


line representing the linear response with the point of maximal response ('bent-stick' model) were in all cases about $20 \%$ lower than those recommended by (US) National Research Council (1978). Curvilinear asymptotic models such as those of Nelder (1966) or Mercer et al. (1977) do not allow the calculation of the optimum dose from the maximum response. To fit our experimental data, a polynomial model was used and the optimum dose was estimated from the maximum response. A similar approach was used by Rosenberg et al. (1959), Schwartz et al. (1958) and Yoshida \& Ashida (1969). This method is criticized as it may lead to erroneous conclusions because the response curve is usually flat in the region of the maximum and its shape is sensitive to the range of input selected (Hegsted, 1964; Morris, 1983). Nevertheless, as can be seen in Table 4, the estimates of the optimum amino acid requirements obtained by this method are in relatively good agreement with recommendations given by (US) National Research Council (1978). There is less similarity between amino acid requirements for maintenance derived from the values presented in the present paper and those of Yoshida \& Ashida (1969). Considerable differences exist also in estimates by other authors (Said \& Hegsted, 1970). These differences are probably due to greater variability in response commonly found under conditions of severe deficiency.

The loss of body $\mathrm{N}$ observed in animals on a diet devoid of one essential amino acid varied with the kind of amino acid omitted. Similar to findings of other authors (Bender, 1965; Said \& Hegsted, 1970), the lowest $\mathrm{N}$ balance was found in rats fed on the S-amino-acid-free diet. Said \& Hegsted (1970) identified threonine-free and isoleucine-free diets together with the diet free of $\mathrm{S}$ amino acids as those which caused the loss of body $\mathrm{N}$ comparable to a protein-free diet, whereas Bender (1965) included in this group valine- and S-amino-acid-free diets. In the present experiments, the loss of body $\mathrm{N}$ on the S-amino-acid-free diet was greater than on any other amino-acid-deficient diet. Nevertheless, the next most striking symptoms of deficiency were found in diets lacking valine, isoleucine or threonine which essentially corresponded with the findings of Said \& Hegsted (1970) and Bender (1965). It seems that the extent of $\mathrm{N}$ loss due to the severe amino acid deficiency depends on the order of limitation of endogenous amino acids which are important precursors of newly synthesized protein under these conditions. It was demonstrated that methionine and threonine were the first two limiting amino acids of endogenous origin and that their supplementation to a protein-free diet had a significant N-sparing effect (Yoshida \& Moritoki, 1974; Yokogoshi \& Yoshida, 1976). It is supposed that the non-essential amino acids are the nextlimiting followed by, as a group, isoleucine, valine and tryptophan (Yokogoshi \& Yoshida, 1981).

In the present study, the smallest loss of body $\mathrm{N}$ was found in diets devoid of histidine or lysine. A low requirement of lysine for maintenance has been documented by many authors (Burroughs et al. 1940; Benditt et al. 1950; Smith \& Johnson, 1967; Said \& Hegsted, 1970). Numerous studies also demonstrated that the body-weight or $\mathrm{N}$ loss due to lysine deficiency was the smallest among the amino acids tested (Ousterhout, 1960; Bender, 1965; Yamashita \& Ashida, 1969; Peng, 1979). The results suggested that in animals fed on the lysine-free diet a certain homeostatic mechanism may operate which prevents lysine degradation and helps the organism to adapt itself to adverse conditions of deficiency (Yamashita \& Ashida, 1969).

In comparison with lysine, there is less information on the effect of a histidine-free diet on growth or N balance. Ousterhout (1960) and Yoshida \& Ashida (1969) reported that the weight loss of animals fed on a histidine-free diet was very low and comparable to a lysine-free diet. Similar results were obtained by Ashida \& Yoshida (1975) in their N-balance studies. A good economy of histidine within the organism was documented also in the isotope studies of Aguilar et al. (1972) who found the lowest level of oxidation of histidine to carbon dioxide of all the essential amino acids. However, the positive $\mathrm{N}$ balance on the 
histidine-free diet was rather surprising. Since there is no reason to suspect that essential amino acids can be synthesized in the body, the most likely explanation of this finding is that it represents an artifact resulting from the balance technique used. An alternative suggestion is that the positive $\mathrm{N}$ balance is a consequence of re-distribution of $\mathrm{N}$ from a protein of higher histidine content to that of lower histidine content or that the rats have acquired some amount of histidine of microbial origin by coprophagy.

In a separate experiment (J. Heger and Z. Frydrych, unpublished results), we have examined the changes in $\mathrm{N}$ deposition in rats fed on lysine-free and histidine-free diets and compared the results obtained by means of balance technique with those of carcass analysis. It was found that the latter technique gave lower values in both cases, even the $\mathrm{N}$ retention in the histidine-free group being negative. The loss of body $\mathrm{N}$ on the histidine-free diet was significantly less that that on the lysine-free diet, but the oppositie was true for the loss of body-weight. The latter finding suggests that some factor other than experimental technique could contribute to the lower $\mathrm{N}$ excretion in the histidine-free group. It is well-known that protein or amino acid deficiency leads to rapid loss of protein from skeletal muscle while the contents of keratin and collagen remain unchanged (Mitchell, 1964). In rats adapted to a protein-free diet, collagen synthesis was observed (Dawson \& Milne, 1976). As the concentration of histidine in both collagen and keratin is very low, it seems reasonable to assume that under the conditions of histidine deficiency and adequate supply of other essential amino acids the amount of histidine degraded from muscle protein is sufficient for the synthesis of collagen or keratin, or both, thus utilizing part of the dietary amino acids. The same effect could result from the intake of histidine by coprophagy which cannot be prevented in a common metabolism cage. The synthesis of collagen or keratin at the expense of other body proteins should naturally result in changes in carcass amino acid composition. Pellett \& Kaba (1972) did not find such changes when feeding a $\mathrm{N}$-free diet but no attention has been paid to this problem as far as the consumption of a histidine-free diet is concerned.

The results from the present study suggest that the process of body protein synthesis is fairly inefficient. With the exception of severe amino acid deficiency, the utilization of limiting amino acid for growth and maintenance was always lower than 1.0 . It could be expected that under these conditions there is a strong metabolic pressure on the maximum utilization of a deficient amino acid; however, contrary to expectations, a considerable amount of the deficient amino acid was apparently catabolized. It is also generally assumed that there is an abrupt decrease in the utilization of essential amino acid as its intake exceeds optimum requirement. We were not able to demonstrate such a change; in fact, the efficiency of utilization decreased almost linearly as the dietary level of amino acids increased from about 60 to $120 \%$ of optimum requirement. It seems, therefore, that the amount of amino acid catabolized gradually increased before an optimum was reached without any marked change at dietary levels above optimum. However, more observations at higher levels of intake would be needed to draw reasonable conclusions in this respect.

Although there were some differences in the utilization of individual amino acids for growth and maintenance the values measured at the same level of deficiency ranged within relatively narrow limits, except for $\mathbf{S}$ amino acids where the utilization was considerably lower. The effect of level of amino acid deficiency was more significant: the efficiency of utilization decreased rapidly as the dietary level of the deficient amino acid increased. These findings should be useful in determining the optimum supplements of amino acids to deficient diets using a N-balance technique.

A low efficiency of utilization of $\mathrm{S}$ amino acids was found also in other studies based on carcass analysis (Pellett \& Kaba, 1972) or on measuring the oxidation of labelled amino acids (Aguilar et al. 1972). It seems that a considerable proportion of dietary methionine is required even under conditions of its deficiency as a donor of methyl groups for the 
synthesis of nucleic acids and other essential compounds such as choline, creatine or methylhistidine as well as the source of $\mathrm{S}$ for the formation of cysteine, taurine and sulphate.

The authors wish to thank Mrs A. Zahradníková and Mr J. Suk for their expert technical assistance, Dr L. Novotný for statistical analysis of results, and Ajinomoto Co., Tokyo, Japan for providing the amino acids.

\section{REFERENCES}

Aguilar, T. S., Harper, A. E. \& Benevenga, N. J. (1972). Journal of Nutrition 102, 1199-1208.

Ashida, A. \& Yoshida, A. (1975). In Proceedings of the 9th Congress of Nutrition, vol. 3, pp. 321-331. Basel: Karger. Associaton of Official Agricultural Chemists (1970). Official Methods of Analysis, pp. 800-801. Washington, DC: Association of Official Agricultural Chemists.

Bender, A. E. (1965). Proceedings of the Nutrition Society 24, 190-196.

Benditt, E. P., Woolridge, C. H., Stefee, C. H. \& Frazier, L. E. (1950). Journal of Nutrition 40, 335-350.

Bunce, G. E. \& King, K. W. (1969a). Journal of Nutrition 98, 159-167.

Bunce, G. E. \& King, K. W. (1969 b). Journal of Nutrition 98, 168-176.

Burroughs, E. W., Burroughs, H. S. \& Mitchell, H. H. (1940). Journal of Nutrition 19, 363-384.

Dawson, R. \& Milne, G. (1976). Proceedings of the Nutrition Society 35, 81A.

Heger, J. Frydrych, Z. \& Froněk, P. (1983). Animal Feed Science and Technology 8, 163-176.

Hegsted, D. M. (1964). In Mammalian Protein Metabolism, vol. 2, pp. 135-171 [H. N. Munro, editor]. New York: Academic Press.

King, K. W. (1963). Federation Proceedings 22, 1115-1121.

Mercer, L. P., Farnell, K. E., Morgan, P. H., Longenecker, H. E. \& Lewis, J. R. (1977). Nutrition Reports International 15, 1-7.

Mitchell, H. H. (1964). In Protein and Amino Acid Metabolism, pp. $11-43$ [A. A. Albanese, editor]. New York: Academic Press.

Morris, T. R. (1983). In Recent Advances in Animal Nutrition-1983, pp. 13-24 [W. Haresign, editor]. London: Butterworths.

National Research Council (1978). Nutrient Requirements of the Laboratory Rat, pp. 13-26. Washington, DC: National Academy of Science.

Nehring, K., Beyer, M. \& Hoffmann, B. (1972). Futtermitteltabellenwerk. Berlin: VEB Deutsche Landwirtschaftsverlag.

Nelder, J. A. (1966). Biometrics 22, 128-141.

Ousterhout, L. E. (1960). Journal of Nutrition 70, 226-232.

Pellett, P. L. \& Kaba, H. (1972). Journal of Nutrition 102, 61-68.

Peng, Y. S. (1979). Journal of Nutrition 109, 1916-1924.

Rosenberg, H. R., Culik, R. \& Eckert, R. E. (1959). Journal of Nutrition 69, 217-228.

Said, A. K. \& Hegsted, D. M. (1970). Journal of Nutrition 100, 1363-1375.

Schwartz, H. G., Taylor, M. W. \& Fisher, H. (1958). Journal of Nutrition 65, 25-37.

Smith, E. B. \& Johnson, B. C. (1967). British Journal of Nutrition 21, 17-27.

Yamashita, K. \& Ashida, K. (1969). Journal of Nutrition 99, 267-273.

Yokogoshi, H. \& Yoshida, A. (1976). Journal of Nutrition 106, 48-57.

Yokogoshi, H. \& Yoshida, A. (1981). Nutrition Reports International 23, 517-523.

Yoshida, A. \& Ashida, K. (1969). Agricultural and Biological Chemistry 33, 43-49.

Yoshida, A. \& Moritoki, K. (1974). Nutrition Reports International 9, $159-168$. 